sible for bringing down the sensitivity of the direct-matching test by almost one-half. It was apparently not suspected that the use of dilute blood would interfere with agglutination of the red cells sensitized by the "blocking" or "incomplete" antibody.

I have been prompted to point out the similarity between the Diamond-Abelson test and the direct-matching test as it was performed in the 'thirties as a possible explanation for the non-recognition, or perhaps non-occurrence, of intra-group transfusion reactions due to the $R h$ factor and not to bring any discredit whatever on the value of the test. Indeed, to us in India, where anti-Rh serum is so hard to obtain, the test has been a real boon as it enables the detection of intra-group incompatibility in the absence of anti-Rh serum and also helps to select a compatible donor. And that is what the clinician is interested in.-I am, etc.,

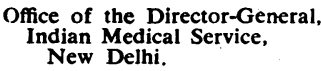

\section{Retrodisplacement and Fertility}

SIR,-Whenever a man states that there is "no shadow of doubt" about an assertion one may know that even he suspects its truth. Dr. Bethel Solomons (April 5, p. 465) asserts that " There is not the slightest doubt that retrodisplacement of the uterus is a cause of sterility." Had he stated that retrodisplacement is frequently associated with lowered fertility there would be less reason to disagree with him.

Some people with retroussé noses have nasal obstruction, but one should not assert that retroussé noses cause nasal obstruction. On the other hand damage to the nasal septum may produce both nasal obstruction and a retroussé nose. It will not cure the nasal obstruction for a plastic surgeon to build a Roman nose, and the obstruction is usually relieved without altering the curve of the external organ.

Retroversion is one of the normal positions of the uterus, though less common than anteversion. Lowered fertility is a frequent concomitant of uterine hypoplasia, and the hypoplastic uterus is very frequently either acutely retroflexed or acutely anteflexed; but it is a bold statement that the position of the uterus causes the failure of conception. To put the uterus in another position will not cure its imperfect development, and as a matter of practical experience does not cure infertility.I am, etc.,

Frank Stabler.

\section{'Reiter's Syndrome}

SIR,- In the interesting annotation on Reiter's syndrome (April 12, p. 495) it is noted that this condition is apparently confined to young adult males.

Two cases occurring in women have been described. Details of one are given by Dr. A. Touraine under the title of " pseudogonococcie entéritique" (Ann. Derm. Syph., Paris, 1946, 6, 687). The other case, described by W. Lever and G. $M$. Crawford (Arch. Derm. Syph., Chicago, 1944, 49, 389), is cited by $A$. Touraine and $A$. Ruel in a very comprehensive survey of the subject (Ann. Derm. Syph., Paris, 1946, 6, 61).-I am, etc.,

London, S.W.1.

JAMES Marshall.

SIR,-I read in your annotation (April 12, p. 495) that Reiter's disease is apparently confined to young adults.

It might be of interest to report that three months ago I attended a man of 58 who had this disease. It began with painful haematuria following in three days with bilateral conjunctivitis, and two days later an arthritis of the right ankle. The urethritis cleared in a week and the conjunctivitis in five days, but the arthritis became increasingly painful, and both knees were affected ten days from the onset of the original symptoms. Eventually his only relief was from diathermy and spa treatment. This man had no venereal history, nor had he ever had any dysentery. Four years previously he had had arthritis in the right knee, and presumably this had left him susceptible to a recurrence of arthritic symptoms.-I am, etc.,

\section{Curare}

SIR,-Having followed the recent correspondence on the condition of shock and respiratory depression associated with the use of curare, commencing with a letter by Dr. Massey Dawkins (Jan. 18, p. 111), with considerable interest, it is felt that the following points are pertinent.

Respiratory depression caused by anaesthetic agents, whether due to their action on the respiratory centre or on the respiratory musculature, is associated, first, with an increase in the $\mathrm{CO}_{2}$ tension and, secondly, with a decrease in the $\mathrm{O}_{2}$ tension. To understand this it is necessary to realize the underlying physiological facts. The optimum number of respirations for elimination of $\mathrm{CO}_{2}$ with a tidal air of about $500 \mathrm{ml}$. is approximately 16 per minute in a person having a normal basal metabolic rate. However, the amount of oxygen available for normal tissue respiration is four times the value necessary; so by this it can be seen that the important factor in respiratory depression is $\mathrm{CO}_{2}$ accumulation and not anoxaemia. $\mathrm{CO}_{2}$ accumulation when about $7 \%$ causes a rise of blood pressure through its central action on the vasomotor centre; at lower concentration the $\mathrm{CO}_{2}$, having a peripheral dilating effect on the arterioles, causes the central effect to be counterbalanced.

Some interesting work has recently been published by $R$. D. Dripps in America (Anesthesiology, 1947, 8, 15), where he has shown that a fall in blood pressure following cyclopropane anaesthesia is associated with a high $\mathrm{CO}_{2}$ tension in the blood during operation. This also is probably the mechanism of the condition of shock occurring after the use of curare where marked respiratory depression has occurred without adequate $\mathrm{CO}_{2}$ elimination. In using curare $\mathrm{I}$ have made a practice of not administering it within half an hour of the expected termination of an operation, but if increased relaxation is required $I$ increase the concentration of the anaesthetic agent $I$ am using, and so avoid causing respiratory depression lasting from 15 to 30 minutes.

With this $\mathrm{CO}_{2}$ accumulation theory in view $\mathrm{I}$ do not ever add $\mathrm{CO}_{2}$ to the anaesthetic mixture, but if there is not a good respiratory exchange at the closing stages of the operation I give a few minutes of " aided" respiration by pressure on the reservoir bag, having first "blown off " the anaesthetic gases.

Since having followed this routine I have had no cases of shock following curare administration, except on one occasion when I found I had been using non-acting soda-lime in a closedcircuit apparatus.-I am, etc.,

Leamington Spa.

GeOFFrey L. WAY.

Sir,- In his letter dealing with the post-operative anoxaemia allegedly attributable to the use of curare, Dr. W. M. Maidlow (April 5, p. 466) invokes total carbon dioxide absorption in closed circuits as a more culpable factor. In support of his contention that absorption should be but partial or intermittent he asserts that "the carbon dioxide in the circuit causes dissociation of oxygen from oxyhaemoglobin in the tissues." The italics are mine, and I would submit, Sir, that what promotes the dissociation of oxyhaemoglobin in the tissues is the carbon dioxide tension in the tissues. This tension is normally higher than that in the alveoli. Under resting conditions the relative figures are 46 and $40 \mathrm{~mm}$. $\mathrm{Hg}$. If this normal carbon dioxide tension gradient is reversed, by either incomplete absorption or the addition of carbon dioxide artificially to the inspired gases, it becomes easier for the oxyhaemoglobin to dissociate in the lungs than in the tissues, and the blood leaves the lungs having secured rather less oxygen than it would otherwise have done. In fact the tissues have not been "given the benefit" which was intended. Left to themselves the tissues will by their own respiration build up a local carbon dioxide tension conducive to oxyhaemoglobin dissociation, and we can raise that local tension only at the expense of a similar rise in the alveolar tension-the old dilemma of the swings and the roundabouts.

It is true that any patient in first- or second-plane inhalation anaesthesia will breathe less deeply if he is put into a circuit with total absorption, and if the atmosphere he was breathing was just sufficient to maintain oxygenation he will now become anoxic. But since it is the usual practice to use oxygen-enriched atmosphes in closed cricuits this situation does not arise during 